\title{
CORRIGENDUM
}

Genes \& Development 34: 1735-1752 (2020)

\section{Corrigendum: FGF signaling regulates development by processes beyond canonical pathways}

Ayan T. Ray, Pierre Mazot, J. Richard Brewer, Catarina Catela, Colin J. Dinsmore, and Philippe Soriano

The above-mentioned article contained an error in Figure 6A. Two panels shown in the scratch assay of serum-treated Fgfr1 $1^{+/ c K O} ; \mathrm{Fgfr} 2^{+/ c K O}$ and Fgfr $1^{c K O / c K O} ; \mathrm{Fgfr} 2^{c K O / c K O}$ cells were the same, as the wrong file was used for the Fgfr1 ${ }^{+/ c K O}$; Fgfr2 ${ }^{+/ c K O}$ panel. Figure 6 has now been corrected in the article online. The conclusions of the manuscript are not affected as all cells spread equivalently under these conditions. The authors apologize for this error.

doi: $10.1101 / \operatorname{gad} .348503 .121$ 


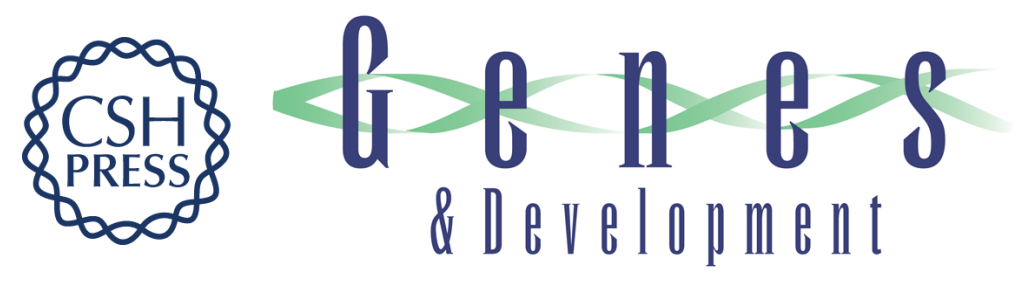

\section{Corrigendum: FGF signaling regulates development by processes beyond canonical pathways}

Ayan T. Ray, Pierre Mazot, J. Richard Brewer, et al.

Genes Dev. 2021, 35:

Access the most recent version at doi:10.1101/gad.348503.121

\section{Related Content}

FGF signaling regulates development by processes beyond canonical pathways Ayan T. Ray, Pierre Mazot, J. Richard Brewer, et al.

Genes Dev. December , 2020 34: 1735-1752

\section{License}

Email Alerting

Receive free email alerts when new articles cite this article - sign up in the box at the top Service right corner of the article or click here.

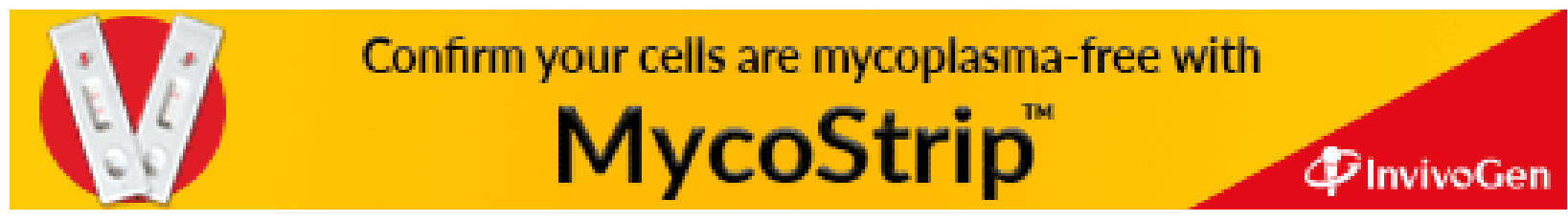

